\title{
Studies on the inheritance of some characters in pumpkins (Cucurbita moschata Poir.).
}

\author{
M.K. Hatem \\ Vegetables Breeding Dept. Hort. Res. Inst., Agricultural Research Center (ARC), Giza -Egypt
}

\begin{abstract}
These experiments were carried out at El-Kanater El-Khyreia, Horticulture Research Station of Hort. Res. Institute, during three successive summer seasons of 2012, 2013 and 2014. Two pumpkins, Cucurbita moschata Poir. viz., White Libi and Balady were used in studying the inheritance of average fruit weight, fruit shape index, flesh thickness, total carbohydrates, total soluble solids (TSS) and $\beta$ carotene contents. In 2012 the two parents were planted in the field during summer season to produced the $\boldsymbol{F}_{\mathbf{1}}$ seeds. In summer season of 2013 the $F_{1}$ plants were selfed to produce the require $F_{2}$ seeds. In the third season, the four populations, i.e., $\boldsymbol{P}_{1}, P_{2}, \boldsymbol{F}_{1}$ and $F_{2}$, were evaluated . The estimated heritability values were $74.8 \%$ for average fruit weight, $82.5 \%$ for fruit shape index, $69.4 \%$ for flesh thickness, $76.3 \%$ for total carbohydrates, $66.6 \%$ for total soluble solids and $63.4 \%$ for $\beta$ carotene content. Data obtained indicated that all characters are controlled by $2-$ 5 pairs of gene. Complete dominance for high parent was found in total carbohydrates and complete dominance for the low parent was found in fruit shape index. Partial dominance for the high parent was found in average fruit weight, flesh thickness and $\beta$ carotene content. Incomplete dominance was found in total soluble solids (TSS). Obtained high broad sense heritability for all studied attributes, lead to suggest that considerable improvement through breeding and selection could be achieved.

In conclusion, these results demonstrate the possibility of improving the breed specifications cultivar Balady by hybridization with cultivar white Libi leading to improved fruiting specifications for this product.
\end{abstract}

Key words: Pumpkin - Inheritance- Heritability - Heterosis - Potence ratio - Complete dominance- number of genes.

\section{Introduction}

Genetic information on pumpkin could be obtained from wide intervarietal crosses, which need to be available before proceeding with the formulation of appropriate breeding strategies to develop and improve fruit quality.

Some authors have reported that pumpkin fruits have high medicinal values (Jones 1996; Keles et al., 2001; Sentu and Debjani 2007; Abd El- Aziz and Abd El-Kalek 2011). The different parts of plant have also been used as medicine in the developed world and the leaves are haemostatic, analgesic, and also used externally for treating burns. Traditionally, the pulp is used to relieve intestinal inflammation or enteritis dyspepsia and stomach disorders. Pumpkin is relatively high in energy and carbohydrates and good source of vitamins, especially high carotenoid pigments and minerals (Bose and Som 1998; Tindall, 2001). Pumpkin seed is as excellent source of protein and also has pharmacological activities such as anti-diabetic (Li et al., 2003), antifungal (Wang and Ng, 2003), antibacterial and antiinflammation activities (Fu et al., 2006) and antioxidant effects (Nkosi et al., 2006).

The success of any crop improvement program depends, on the amount of genetic variability present in the population. Very few research works relating to variability of pumpkin accessions have been conducted in Egypt. So, intensive research efforts are needed in several areas particularly for selection of superior pumpkin genotypes. There is wide genetic variability among the existing pumpkin accessions (Ferrial et al., 2003 and 2004; Aruah et al., 2010; Aliu et al., 2011) and thus, the utilization of such variability in the crop's breeding programmes is possible. The breeding programs depend on the knowledge of key traits, genetic systems controlling their inheritance, genetic and the environmental factors that influence their expression. Presently, there is dearth of information about the genetic systems controlling their inheritance in the crop.

Fruit yield is a complex character that is determined by complex associations among several agronomic traits (Chandra et al., 1990; Rao et al., 1990).

Furthermore, very limited attempt has been made for genetic improvement of the crop. Heterosis or hybrid vigour can play a vital role in increasing the yield quality of pumpkin. It refers to the phenomenon in which $\boldsymbol{F}_{\mathbf{1}}$ hybrid obtained by crossing of two genetically dissimilar inbred lines or genotypes, shows increased or decreased vigour over 
the better parent or mid-parent value (Pohlman, 1979).

Abd El-Rahman et al., (2000) showed that fruit weight was quantitatively inherited and over dominance was existed in pumpkin (Cucurbita moschata). They added that broad sense heritability was $32.7 \%$, while narrow sense heritability was $29.4 \%$ and one to three pairs of gene control this character. As fruit shape index, dominance to round fruit was existed and one pair of genes control the trait. Broad sense heritability was $67.2 \%$. They found that, chemical composition indicated that the fruit's rind was higher in protein and lipids than the flesh. Therefore, the object of this work was to study the genetic behavior of some economic fruit characters of pumpkin.

The heterotic effects and genetic components of variation for qualitative and quantitative characters were estimated in sweet gourd (Cucurbita moschata Duch. ex Poir). The phenotypic coefficients of variation were higher than genotypic one for all the character, indicating that the environment played a consider role on the expression of these characters. High heritability coupled with high genetic advance were found in parents and hybrid for number of fruits per plant, individual fruit weight and fruit yield suggesting that improvement would be effective through phenotypic selection (Jahan et al., 2012). They added that, both positive and negative heterosis was observed for different qualitative and quantitative characters in $\boldsymbol{F}_{\mathbf{1}}$ hybrids of sweet gourd. None of the hybrids exhibited maximum heterosis for all traits, but significant and desirable level of heterosis over midparents and better parent was obtained in several hybrids.

Sudhakar et al., (2010) found the improvement of traits like flesh thickness, total carotenoids and ascorbic acid, selections could be made, while fruit yield may be improved through hybridization programs.

Therefore, this study was carried out to plan efficient pumpkin breeding programs, also to have an understanding of its genetic and breeding systems, information on the character association in pumpkin.

\section{Materials and Methods}

This investigation was carried out at ElKanater El-Khyreia Horticulture Research station Institute. In summer 2013 and 2014. The crosses were made between the parents $\boldsymbol{P}_{\mathbf{1}}$ (White Libi) and $P_{2}$ (Balady) to produce $\boldsymbol{F}_{\mathbf{1}}$ seeds. $\boldsymbol{F}_{\mathbf{1}}$ plants were selfed to produce the $F_{2}$ seeds. In summer season of 2014 , the two parents $\left(\boldsymbol{P}_{\mathbf{1}} \& \boldsymbol{P}_{2}\right)$, $F_{1}$ and $F_{2}$ were evaluated in a randomized complete blocks design with three replicates. Each replicate included 15 plants of each $\boldsymbol{P}_{\mathbf{1}}, \quad P_{2}$ and $\boldsymbol{F}_{1}$ and 48 plants of $\boldsymbol{F}_{2}$. All cultural practice were carried out according to the recommendation followed for pumpkin crop during the growing seasons. 4,6 and 7 of March

The parents, $\boldsymbol{F}_{\mathbf{1}}$ and $\boldsymbol{F}_{2}$ seeds were sown on first March 2012, 2013 and 2014. The plot consisted of three row 5.0 meters long and $2.5 \mathrm{~m}$. for each row in $\boldsymbol{P}_{\mathbf{1}}, \boldsymbol{P}_{2}$ and $\boldsymbol{F}_{\mathbf{1}}$ while 10 rows for $F_{2}$ plants, the spacing within plants was one meter. The fruits were harvested at ripe stage. Observation and measurements were recorded on an individual plant basis.

The recorded data were as follows:-

a) The average fruit weight was calculated in $\mathrm{kg}$.

b) Fruit shape index, was calculated the ratio of the polar diameter by transverse diameter of the fruit.

c) Flesh thickness was calculated in $\mathrm{cm}$. of the fruit.

d) Chemical composition:

1- Total carbohydrates:- Total carbohydrates content was determined in skin and flesh for the fruits parents, $F_{1}$ and $F_{2}$ populations according to the method of Montgomery (1961).

2- Total soluble solids (TSS \%) content: - The total soluble solids content (TSS) was determined by the hand refractometers.

3- $\beta$ carotene content:- $\beta$ carotene content for the flesh of the fruits according to A.O.A.C. (1975).

Means, variances, and standard error were computed for each population. Population means were compared by least significant difference (L.S.D.) according to Snedecor and Cochran (1973)

Various genetic parameters were estimated according to Warner et. al., (1980).

1- Average degree of heterosis (ADH\%):- Based on MP or mid-parents heterosis = $\bar{F}_{1}-M P / M P * 100$

Based on HP or better parent heterosis= $\overline{F_{1}}-\overline{H P} / \overline{H P} * 100$

2- Potence ratio (P.R.) $=\bar{F}_{1}-M P / \frac{1}{2}\left(\overline{P_{2}}-\overline{P_{1}}\right)$

3- $\quad$ Inbreeding

$\left(\overline{F_{1}}-\overline{F_{2}} / \overline{F_{1}}\right) * 100$

4- Environmental variance $(\mathrm{E})=$ $V P_{1}+V P_{2}+V F_{1} / 3$

5- Genetical variance $(\mathrm{G})=V F_{2}-E$

6- Heritability:- Broad sence $h_{b}^{2}=$ $\left(\left(V F_{2}-V E\right) / V F_{2}\right) * 100$

7- The minimum number of genes:- 
The numbers of effective factors controlling the measured trait were calculated using by:- Castl and Wright formula (1921) and Burton (1951).

\section{Results and Discussion}

Data of the studied characters for $\boldsymbol{P}_{\mathbf{1}}, P_{2}, \boldsymbol{F}_{\mathbf{1}}$ and $F_{2}$ populations of the cross " White Libi $\mathrm{X}$ Balady" are given in Table 1 . The analysis of variance indicated that there were significant differences among the studied generations in all characters under study.

\section{1- Average fruit weight:}

The two parental cultivars ( $\boldsymbol{P}_{\mathbf{1}}$ ) White Libi and $\left(P_{2}\right)$ Balady showed significant difference in average fruit weight. Their means were 6.426and $3.71 \mathrm{Kg}$., respectively. The White Libi line significantly exceeded Balady by about $2.716 \mathrm{~kg}$.. The $\mathrm{ADH} \%$, based on the MP values was estimated as $15.36 \%$ in this cross, indicating dominance towards the high fruit parent. Partial dominance for the high fruit for average fruit weight was detected in these cross, since it showed significant negative $\mathrm{ADH}$ values in relation to high parents. These values were $(-9.03 \%)$ for this cross. The estimated potence value (0.57) was in accordance with the suggested positive partial dominance and additive effects hypothesis (Table $1 \&$ Fig. 1). Similar results were obtained by Jahan et al., 2012.

The $\boldsymbol{F}_{\mathbf{1}}$ frequency distribution was skewed towards the high parent, due to the partial dominance of the large fruit. Significant difference between the actual means of the $\boldsymbol{F}_{1}$ and $\boldsymbol{F}_{2}$ supporting the partial dominance of the high fruit weight.

Variances of the non-segregating populations i.e., $\boldsymbol{P}_{1}, P_{2}$ and $\boldsymbol{F}_{1}$ were different, indicating that the environmental variance varies considerable among different genotypes (Table 1). However their variances were less than those of $\boldsymbol{F}_{2}$, this indicates that their homogeneity was higher than that of $\boldsymbol{F}_{2}$ populations which had greater variance.

Table 1. Estimates of genetic parameters for average fruit weight, shape index, flesh thickness, total carbohydrates, total soluble solids (TSS) and $\beta$ carotene content.

\begin{tabular}{|c|c|c|c|c|c|c|}
\hline $\begin{array}{l}\text { Characters } \\
\text { Parameters }\end{array}$ & $\begin{array}{l}\text { Average } \\
\text { fruit } \\
\text { weightkg }\end{array}$ & $\begin{array}{l}\text { Fruit shape } \\
\text { index }\end{array}$ & $\begin{array}{c}\text { Flesh } \\
\text { thickness } \\
\mathrm{cm}\end{array}$ & $\begin{array}{c}\text { Total } \\
\text { carbohydrates \% }\end{array}$ & $\begin{array}{c}\text { Total soluble } \\
\text { solids } \\
\text { (TSS). } \%\end{array}$ & $\begin{array}{c}\beta \text { carotene } \\
\text { content }\end{array}$ \\
\hline Mean $\left(\mathrm{P}_{1)}\right.$ & $6.426 \pm 0.05$ & $0.91 \pm 0.01$ & $5.89 \pm 0.07$ & $17.18 \pm 0.01$ & $10.78 \pm 0.09$ & $9.21 \pm 0.10$ \\
\hline Mean $\left(\mathrm{P}_{2}\right)$ & $3.71 \pm 0.05$ & $1.31 \pm 0.01$ & $3.38 \pm 0.06$ & $15.49 \pm 0.04$ & $8.13 \pm 0.06$ & $14.35 \pm 0.14$ \\
\hline Mean (MP) & 5.07 & 1.11 & 4.64 & 16.33 & 9.45 & 11.78 \\
\hline Mean $\left(F_{1}\right)$ & $5.85 \pm 0.05$ & $0.93 \pm 0.01$ & $5.09 \pm 0.05$ & $17.19 \pm 0.2$ & $9.53 \pm 0.09$ & $13.78 \pm 0.08$ \\
\hline Mean $\left(\mathrm{F}_{2}\right)$ & $5.266 \pm 0.05$ & $0.93 \pm 0.01$ & $5.26 \pm 0.06$ & $17.19 \pm 0.02$ & $9.66 \pm 0.09$ & $13.77 \pm 0.07$ \\
\hline $\mathrm{S}^{2}\left(\mathrm{P}_{1}\right)$ & 0.134 & 0.0004 & 0.228 & 0.001 & 0.397 & 0.455 \\
\hline $\mathrm{S}^{2}\left(\mathrm{P}_{2}\right)$ & 0.101 & 0.0005 & 0.097 & 0.069 & 0.164 & 0.893 \\
\hline$S^{2}\left(F_{1}\right)$ & 0.126 & 0.003 & 0.116 & 0.026 & 0.375 & 0.274 \\
\hline $\mathrm{S}^{2}\left(\mathrm{~F}_{2}\right)$ & 0.477 & 0.017 & 0.480 & 0.140 & 0.934 & 1.472 \\
\hline $\mathrm{ADH} \%$ & & & & & & \\
\hline MP & $15.36 * *$ & $-16.33 * *$ & $9.87 * *$ & $5.23 * *$ & 0.85 & $16.97 * *$ \\
\hline HP & $-9.03 * *$ & $-29.24 * *$ & $-13.62 * *$ & 0.04 & $-11.55 * *$ & $-3.97 * *$ \\
\hline $\begin{array}{l}\text { Potense ratio } \\
\text { (P.R.) }\end{array}$ & 0.57 & -0.90 & 0.36 & 1.01 & 0.06 & 0.78 \\
\hline $\begin{array}{l}\text { Inbreeding } \\
\text { depression (ID } \\
\%\end{array}$ & 9.92 & -15.61 & -3.37 & 9.31 & -1.326 & 7.36 \\
\hline $\begin{array}{l}\text { Environmental } \\
\text { variance. }\end{array}$ & 0.12 & 0.01 & 0.15 & 0.03 & 0.312 & 0.54 \\
\hline $\begin{array}{l}\text { Genetical } \\
\text { Variance }\end{array}$ & 0.36 & 0.02 & 0.33 & 0.11 & 0.622 & 0.93 \\
\hline $\begin{array}{l}\text { Heritability }\left(h_{b}^{2}\right) \\
\% \text {. }\end{array}$ & 74.76 & 82.49 & 69.36 & 76.28 & 66.56 & 63.39 \\
\hline $\begin{array}{l}\text { No. of gene. } \\
\text { 1-Castle \& } \\
\text { Wright. }\end{array}$ & 2.63 & 1.57 & 2.17 & 3.16 & 1.57 & 3.75 \\
\hline 2- Burton. & 5.31 & 2.20 & 5.07 & 4.71 & 4.53 & 3.58 \\
\hline
\end{tabular}

$P_{1}=$ White Libi and $P_{2}=$ Balady . 
Fig. 1: Distribution of average fruit weight (Kg.) in parental lines, $\boldsymbol{F}_{\mathbf{1}}$ and $\boldsymbol{F}_{\mathbf{2}}$ plants for the cross (White Libi x Balady).

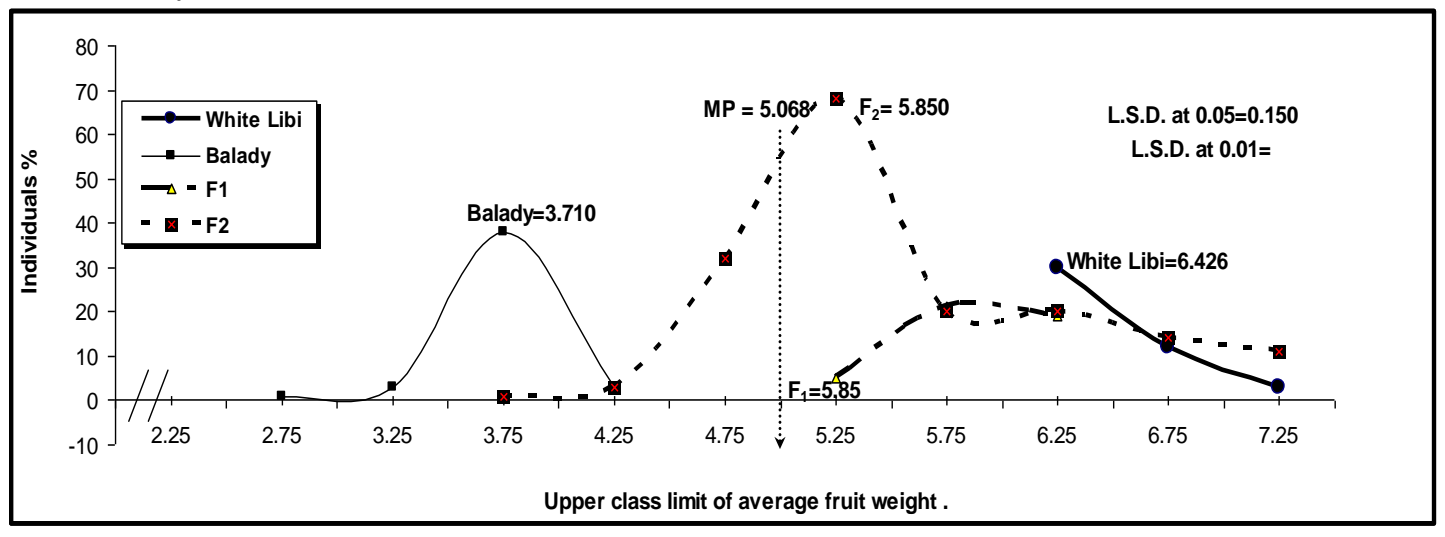

The distribution of the $\boldsymbol{F}_{2}$ plants for this cross stretched over a wide range as weight of fruit scale. About $60.00 \%$ of the $\boldsymbol{F}_{2}$ plants for this cross was covered the range exhibited by the high parent (White Libi) and $\boldsymbol{F}_{\mathbf{1}}$ populations. The remaining $\boldsymbol{F}_{2}$ plants $(40 \%)$ covered the range exhibited by the recessive parent (Balady) and $\boldsymbol{F}_{\mathbf{1}}$ plants.

The minimum number of genes was estimated as 2.63 and 5.31 according to Castle \& Wright and Burton formulae, respectively. The broad sense heritability $\left(h_{b}^{2}\right)$ was estimated as $74.76 \%$. The $\mathrm{BSH}$ obtained indicates that average fruit weight is controlled by many genes and accordingly affected by environmental factors. These results are agree with those of Abd El-Rahman et al., (2000) who found that fruit weight was quantitatively inherited with over dominance effects existed in pumpkin.
It could be concluded that the average fruit weight is controlled by more than two pairs of gene with mostly additive gene actions and partial dominance for the high weight.

\section{2- Fruit shape index:}

The two parental lines $\left(\boldsymbol{P}_{\mathbf{1}}\right)$ White Libi and $\left(P_{2}\right)$ Balady showed significant difference in fruit shape index. The White Balady line significantly exceeded White Libi by about 0.4 . Their means were 0.91 and 1.31 , respectively. The $\boldsymbol{F}_{\mathbf{1}}$ mean (0.93) was very close to that of the low parent, indicating dominance for the low fruit shape index. The estimated $\mathrm{ADH} \%(-29.24 \%)$ and potence ratio (-0.9) support the dominance hypothesis.

These results suggesting complete dominance for the low fruit shape index (Table 1).

Fig. 2. Distribution of fruit shape index in parental lines, $\boldsymbol{F}_{1}$ and $\boldsymbol{F}_{2}$ plants for the crosses (White Libix Balady).

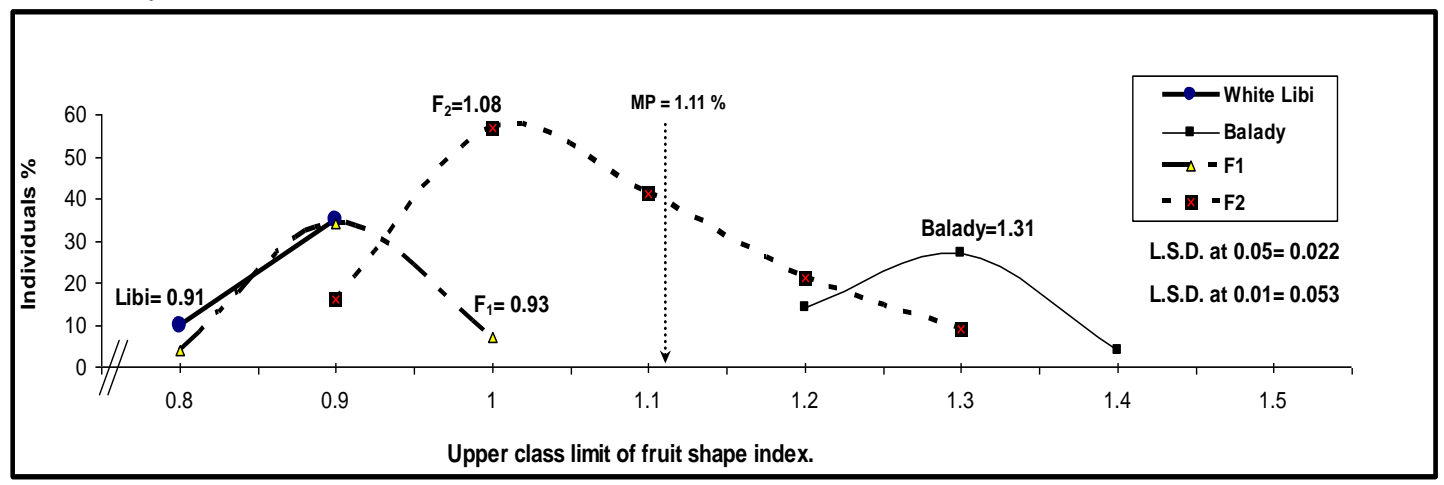

The distribution of the $\boldsymbol{F}_{2}$ plants stretched over a wide range as fruit shape index scale. About $20.83 \%$ of the $\boldsymbol{F}_{2}$ plants covered the range exhibited by the high parent (Balady). And the remaining $\boldsymbol{F}_{2}$ plants were $(79.17 \%)$ covered the range exhibited by the round parent (White Libi) and $\boldsymbol{F}_{\mathbf{1}}$ plants. This figure suggests that the character is controlled by 1-2 pair of genes. 
The monosonic inheritance is verified by the high heritability $(82.49 \%)$. These high values suggested that progress could be made in fruit shape index of pumpkin by selection within segregating progenies. The minimum number of genes was estimated as 1.57 and 2.20 according to Castl-Wright and Burton formulae, respectively. Abd El-Rahman et al., (2000) found that, adominance to round fruit was existed and one pair of genes control the character. Broad sense heritability was $67.2 \%$.

It appears from the examination of data presented that this trait is simply inherited mostly complete dominance for the low fruit shape index (round fruit).

\section{3- Flesh thickness:}

Highly significant difference between the two parental lines was observed in flesh thickness. The White Libi line significantly exceeded Balady by about $2.51 \mathrm{~mm}$.

The $\mathrm{ADH} \%$ was estimated as $9.87 \%$ based on MP and as $-13.62 \%$ based on high parents content suggesting partial dominance for the high flesh thickness. The estimated potence values $(-0.36)$ for this cross is in accordance with this suggestion (Table 1).

The $\boldsymbol{F}_{1}$ distribution for the cross was skewed towards the high parental line, as expected according to the partial dominance of the high flesh thickness (Fig. 3).

Estimated BSH $(69.36 \%)$ was approximately similar to Sudhakar, et al., (2008) who found the heritability for this trait was $68.30 \%$. The minimum number of genes was estimated as 2.17and 5.07according to Castl-Wright and Burton formulae, respectively for this cross.

It appears from the examination of data presented that this trait is controlled by $2-5$ pairs of genes with partial dominance for the high flesh thickness.

The distribution of the $\boldsymbol{F}_{2}$ plants for this cross stretched over a wide range as flesh thickness of fruit scale. About $93.75 \%$ of the $\boldsymbol{F}_{2}$ plants was covered the range exhibited by the high parent (White Libi) and $\boldsymbol{F}_{\mathbf{1}}$ populations. But the remaining $\boldsymbol{F}_{2}$ plants about $(6.25 \%)$ covered the range exhibited the recessive parent (Balady). This distribution (90:10) lied to suggest that this trait is controlled by 1-2 pair of genes. The estimate number of genes may be due to the environmental effects or to low size of the studied plants in $\boldsymbol{F}_{2}$ population

Fig. 3. Distribution of flesh thickness (cm.) in parental lines, $\boldsymbol{F}_{\mathbf{1}}$ and $\boldsymbol{F}_{2}$ plants for the crosses (White Libi x Balady).

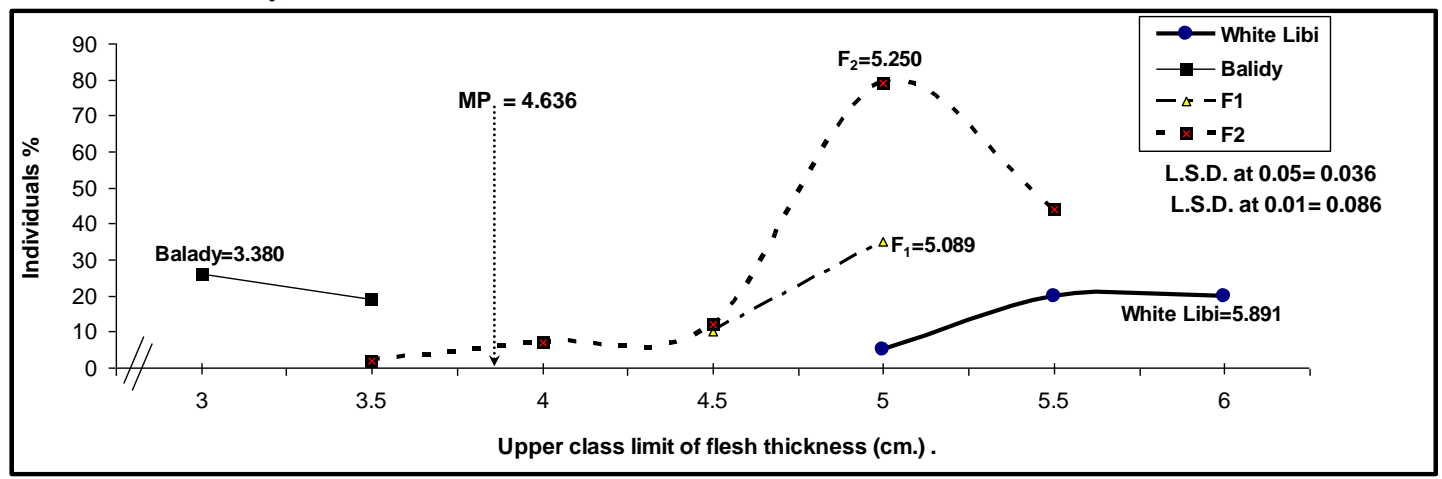

\section{4- Total carbohydrates:}

Data presented in Table (1) and Fig. (4) show highly significant difference between the two parental lines in total carbohydrates in fruit. The White Libi line significantly exceeded Balady by about $1.69 \mathrm{gm} . / 100 \mathrm{gm}$.

The ADH\% was estimated as $5.23 \%$ and 0.04 based on MP and better parent, respectively, suggesting complete dominance for the high total carbohydrates. Complete dominance for the high total carbohydrates was verified by the estimated potence value $(1.01 \%)$.
The distribution of the $\boldsymbol{F}_{2}$ plants showed that most plants lied in the area of the low parent Balady. This figure disagrees with the expected distribution when the character is controlled by dominance genes of the high contents. This is may be due to the population size of $F_{2}$ is low, or to error in carbohydrate determination. The BSH $\left(h_{b}^{2} \%\right)$ was estimated as $76.28 \%$. Data obtained suggest that this trait may be controlled by many pair of genes with complete dominance for the high carbohydrates content. 
Fig. 4. Distribution of total carbohydrates (gm./100 gm.) in parental lines, $\boldsymbol{F}_{\mathbf{1}}$ and $\boldsymbol{F}_{2}$ plants for the crosses (White Libi x Balady).

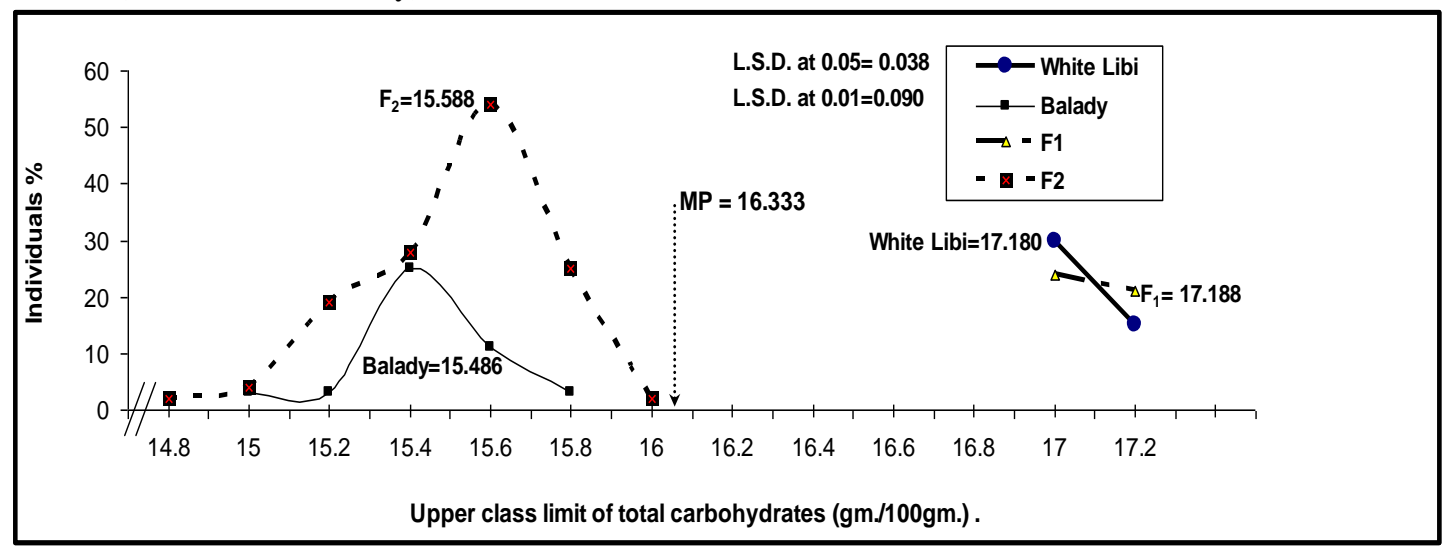

\section{5- Total soluble solids (TSS):}

Data presented in Table (1) and Fig. (5) show highly significant difference between the two parental lines in total soluble solids \% (TSS). The White Libi significantly exceeded Balady by about $2.65 \%$.

Fig. (5): Distribution of total soluble solids $\%$ (TSS) in parental lines, $\boldsymbol{F}_{\mathbf{1}}$ and $\boldsymbol{F}_{\mathbf{2}}$ plants for the crosses (White Libi x Balady).

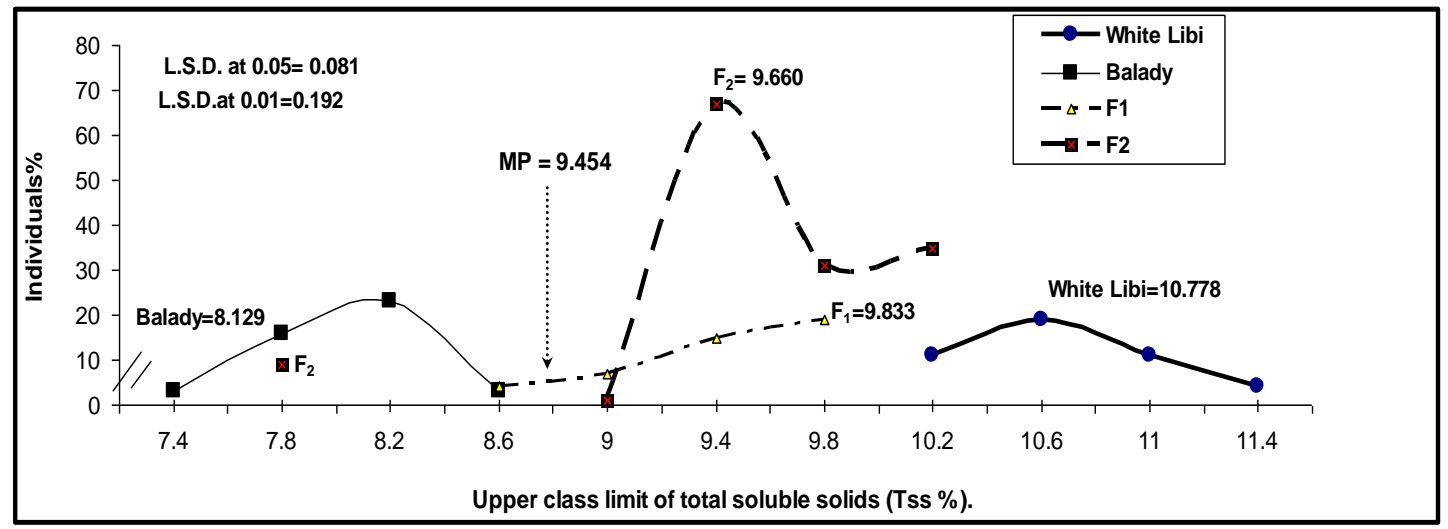

The distribution of the $\boldsymbol{F}_{2}$ plants in this cross was stretched over a wide range of the total soluble solids scale without distinct classes, indicating that the character may be controlled by many genes. About $6.75 \%$ of the plants covered the range exhibited by the low parent Balady populations, 68 . 75\% covered the range exhibited by the $\boldsymbol{F}_{\mathbf{1}}$ and about $24.31 \%$ of the $\boldsymbol{F}_{2}$ plants covered the range exhibited by the high parent Libi populations. The minimum number of genes for this cross was estimated as 1.57 and 4.53 according to Castle-
Insignificant MP heterosis value (0.85) was estimated also low potence value (0.06) was found. character is controlled by no-dominance genes.

The $\boldsymbol{F}_{\mathbf{1}}$ frequency distribution was skewed towards the mid-parents, supporting the nodominance hypothesis. From these estimation, it could be concluded that this 
Fig. (6): Distribution of $\beta$ carotene content (gm./100 gm.) in parental lines, $\boldsymbol{F}_{\mathbf{1}}$ and $\boldsymbol{F}_{2}$ plants for the crosses (White Libi x Balady).

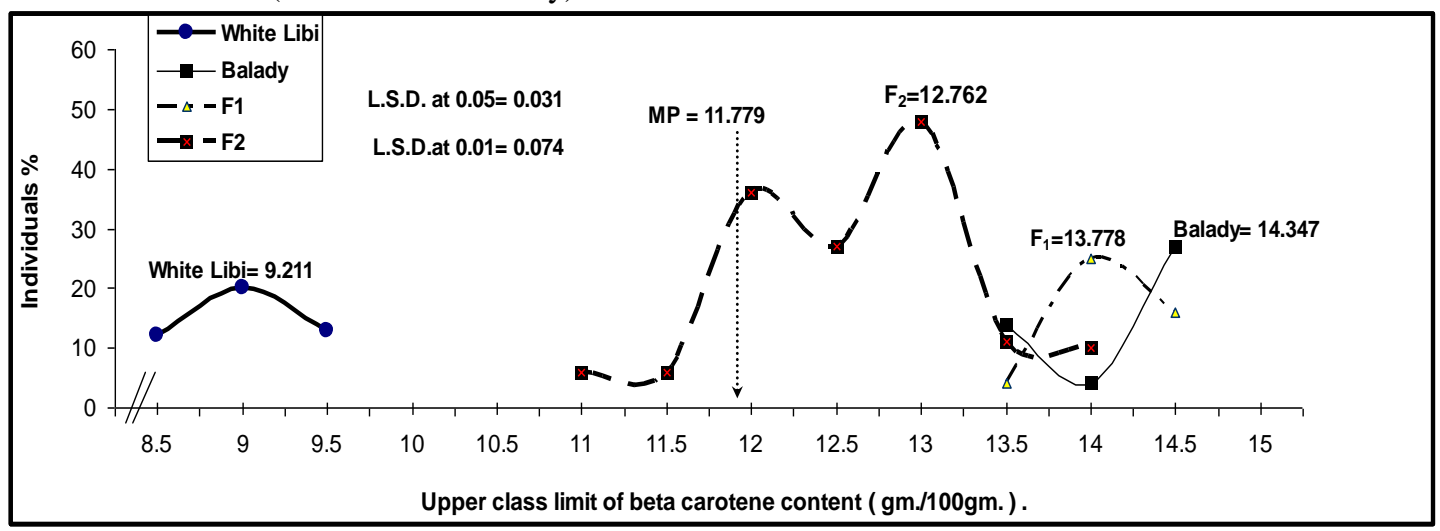

Significant differences were observed between obtained (13.778 gm./100gm.) and expected (11.78 gm./100gm.) arithmetic means of the $\boldsymbol{F}_{\mathbf{1}}$ populations. Sudhakar et al., (2003) found that $\beta$ carotene content ranged from 2.34 to14.85 gm./100gm.). It is noticed that, the obtained mean was lower than the theoretical one. It could be explained by the strong partial dominance of the high $\beta$ carotene content. The $\mathrm{ADH} \%$, based on the MP value was estimated as 11.779) indicating dominance towards the high $\beta$ carotene content. Partial dominance for the high fruit for $\beta$ carotene content was detected, since it showed significant negative ADH values in relation to high parents. These values were $(-3.97 \%)$ for this cross. The estimated potence values $(0.78)$ was in accordance with the suggested partial dominance and additive effects hypothesis (Table 1). Jahan et al., (2012) reported that both positive and negative heterosis was observed for different qualitative and quantitative characters in $\boldsymbol{F}_{\mathbf{1}}$ hybrids of sweet gourd.

The $\boldsymbol{F}_{1}$ distribution was skewed towards the high parent, due to the partial dominance of the high $\beta$ carotene content in fruit. Significant difference between the actual means of the $\boldsymbol{F}_{1}$ and $\boldsymbol{F}_{2}$ supporting the partial dominance of the low fruit weight. (Table 1).

The distribution of the $\boldsymbol{F}_{2}$ plants for this cross stretched over a wide range as weight scale of fruit. About $14.58 \%$ of the $\boldsymbol{F}_{2}$ plants for this cross was covered the range exhibited by the high parent and $\boldsymbol{F}_{\mathbf{1}}$ populations. While, about $85.417 \%$ of the $\boldsymbol{F}_{2}$ plants was covered range are located between the two parents in the direction of the high parent Fig. (6).

The minimum number of genes was estimated as 3.75and 3.58 according to Castle \& Wright and Burton formulae, respectively. The $\mathrm{BSH}\left(h_{b}^{2}\right)$ was estimated as $63.39 \%$ in this cross. The relatively low $\mathrm{BSH}$ obtained indicates that $\beta$ carotene content in fruit is controlled by many genes and accordingly affected by environmental factors.

It could be concluded that the $\beta$ carotene content in fruit is controlled by more than two pair of genes with partial dominance for the high $\beta$ carotene content in fruit.

\section{References}

Abd El-Aziz, A.B., and H.H. Abd El-Kalek, (2011). Antimicrobial proteins and oil seed from pumpkin (Cucurbita moschata). Nature and Science 9 (3): 105-119.

Abd El-Rahman, M.M.; A.A. Kamooh and M.E. Abou El-Nasr (2000). Genetical and chemical studies on pumpkins (Cucurbit moschata). J. Agric. Sci. Mansoura Univ., 25(2): 1001-1014.

Aliu, S; A. Haziri; S. Fetahu; N. Aliaga; I. Rusinove; I. Haziri and V. Arapi (2011). Morphological and nutritive variation in a collection of Cucurbit pepo L. growing in Kosova. Notulae Scientia Biologiccae 3:(2), 119-122.

A.O.A.C. (1975). Association of official agricultural chemists Official methods of analysis. $12^{\text {th }}$ ed. Washington, D.C.

Aruah, C.B.; M.I. Uguru and B.C. Oyiga (2010). Variations among some Nigerian (Cucurbita Landrace). African . Plant Scie., 4 (10): 374386.

Bose, T.K. and M.G. Som (1998). Vegetable Grops in India, Naya Prokash, Calcutta, India: 92-95.

Burton, G. W. (1951). Quantitative inheritance in pearl millet (Pennisetum Glaucum). Agric. J., 43: 409-417.

Castl, W.E. and S. Wright(1921). An improved method of estimating the number of genetic factors concerned in cases of blending inheritance. Science, 54: 223.

Chandra, A.; B.K. Verma and R.G. Satpute (1990). Evaluation of related chilli lines 
(Capsicum annuиm L.) Vegetable Scie., 7, 4748.

Ferrial, M.; B. Pico and F. Nuez (2003). Genetic diversity of a germplasm collection of Cucurbita pepo ysing SRAP and AFLP markers. Theoretical and Applied Genetics. 107, 271-282.

Ferrial, M.; B. Pico, P. Fernandes de cordova and F. Nuez (2004). Molecular diversity of a germplasm collection of squash (Cucurbita moschata) determined by SRAP and AFLP markers. Crop Sci.,44, 653-664.

Fu, C.L.; S.H. Huan and Q. H. Li (2006). A Review on pharmacological activities and utilization technologies of pumpkin. Plant Foods for Human Nutrition ., 61, 70-77.

Jahan, T.A.; A.K.M.A. Islam; M.G. Rasul; M.A.K. Mian and M.M. Hague (2012). Heterosis of qualitative and quantitative characters in sweet gourd (Cucurbita moschata Duch. Ex Poir). African food, Agriculture Nutrition and Development. 12(3): 6186-6199.

Jones, F.A. (1996). Herbs-useful plants: Their role in history and today. European Journal of Gastroenterology and Heplatology, 8, 12271231.

Keles, O; S.A.K.; T. Bakirel and K. Alpinar (2001). Turkiye'de yetisen bazibitkilerin antibacterial etkisinin incelenmesi. Turkish Veterinary and Animal Scie., 25,559-565.

Li, Q. H.; Z.Tian and T. Y. Cai (2003). Study on the hypoglycemic action of pumpkin extract in diabetic rats. Acta Nutrimenta Sinica 25, 34-36.

Montgomery, R. (1961). Further studies of the phenol sulphuric acid reagent for carbohydrates. Biochem. Biophys. Acta, 84: 591-593.

Nkosi, C. Z.; A. R. Opoku and S. E. Terblanche (2006). Antioxidant effects of pumpkin seeds (Cucurbita pepo) protein isolate in CCL induced liver injury in 4 low-protein fed rats. Phototherapy Research 20, 935-940.
Pohlman, J.M. (1979). Breeding Field Crops. $2^{\text {th }}$ edition Westport, Connection: The AVI Publishing Company, Inc.

Rao, K.S.; R. Dominic ; S. Kirpal; C. Kaluwin; D. E. Rivett; G.P. Jones and K. Singh (1990). Lipids, fatty acid, amino acids and mineral compositions of five edible plant leaves. J. Agric. Food Chem., 38 (12): 2137-2139.

Sentu, S. and G. Debjani (2007). Effect of ripe fruit pulp extract of Cucurbita pepo Linn. In: Aspirin-induced Gastric and Duodenal Ulcer in Rats, S.N. pradhan Center for Neurosciences, University of Calcutta, Kolkata, India, pp 639645.

Snedecor, G.W. and W.G. Cochran(1973). Statistical Methods. iowa State Univ. Press, Ames. Iowa. U.S.A.

Sudhakar Pandey, Jagdish Singh, A. K. Upadhyay, D. Ram and M. Rai (2003). Ascorbate and Carotenoid Content in an Indian Collection of Pumpkin (Cucurbita Moschata DUCH. EX POIR). Cucurbit Genetics Cooperative Report 26:51-53.

Sudhakar Pandey, Shailendra Kumar, B.R. Choudhary, D.S. Yadav and M. Rai (2008). Component analysis in pumpkin (Cucurbita Moschata DUCH. EX POIR). Veg. Sci., 35(1): 35-37.

Sudhakar Pandey, Aastik Jha, Sanjeev Kumar and M. Rai (2010). Genetics and heterosis of quality and yield of pumpkin. Indian J. Hort., 67(3): 333-338.

Tindall, H.D. (2001). Vegetables in the tropics. Macmillan Education, London, 166.

Wang, H.X. and T. B. Ng (2003). Isolation of cucurmoschin: A novel antifungl peptide abundant in arginine, glutamate and glycine residues from black pumpkin seed. Peptides 24, 969-972.

Warner, R.A.; D.C. Sanders and W. R. Handerson (1980). Inheritance of tolerance to Rhizoctonia Fruit Root of tomato. J. Amer. Soc. Hort. Sci. 105(6): 819-822. 


\title{
دراسات على وراثة بعض الصفات فى القرع العسلى.
}

\author{
مَحمُود قَطب حَاتِم \\ قسم بحوث تربية الخضر ـ معهز بحوث البساتين ـ مركز البحوث الزراعية .
}

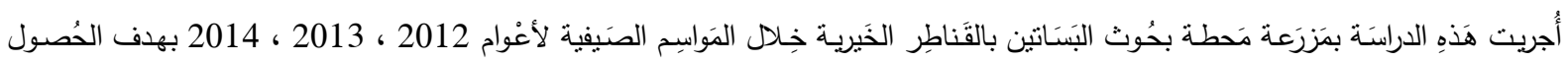

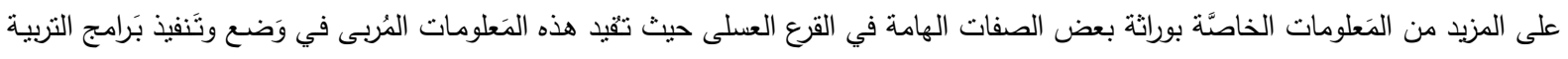

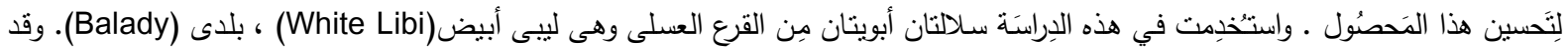

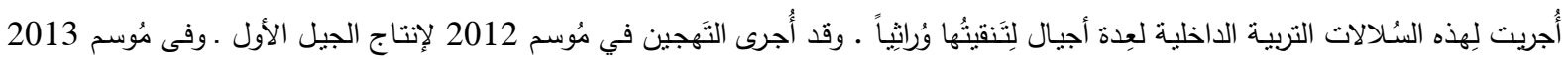

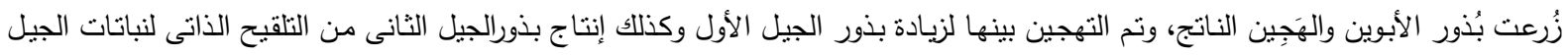

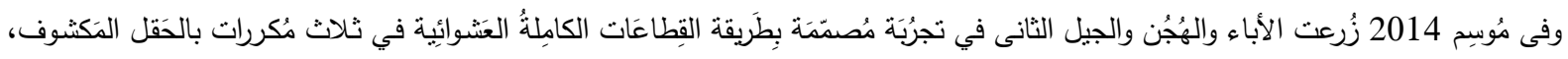

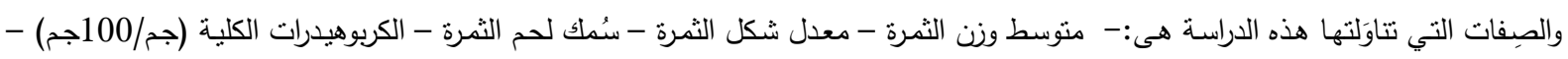

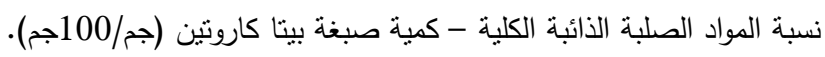

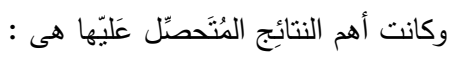
[1] كانت وراثة كل الصفات التى تمت دراستها صِفات كمية التَوريث مع وُجُود سِيادة تامة للأب العالى في محتوى الكربوهيدرات الكلية، وسيادة

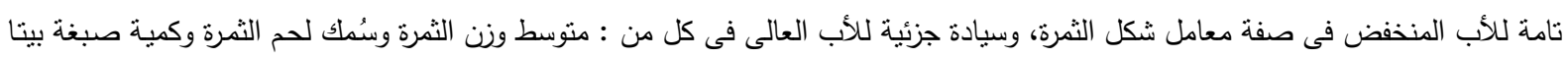
كاروتين. وإنعدام السيادة فى صفة المواد الصلبة الذائبة الكلية.

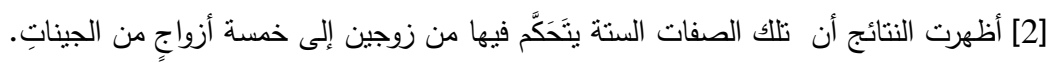

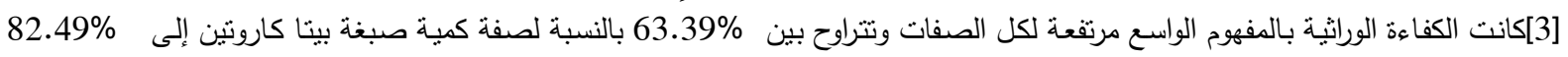
بالنسبة لصفة معامل شكل الثمرة. وبصفة عامة تحمل هذه الننائج إمكانية تحسين مواصفات الصنف البلدى للقرع العسلى عن طريق التهجين مع الصنف الليبى الأبيض مما يؤدى إلى تحسين المواصفات الثمرية لهذا الصنف. 